\title{
Geographical distribution of Corydoras micracanthus Regan 1912 (Siluriformes: Callichthyidae), with comments on its behavior and type locality
}

\author{
Felipe ALONSO ${ }^{1,2^{*}}$, Guillermo Enrique TERÁN ${ }^{2,3}$, Pablo Andrés CALVIÑO², Gastón AGUILERA ${ }^{3}$ \\ \& Juan Marcos MIRANDE ${ }^{3}$ \\ ${ }^{1}$ Instituto de Bio y Geociencias del NOA (IBIGEO)-CONICET. 9 de julio 14. Rosario de Lerma-4405. Provincia \\ de Salta, República Argentina. ${ }^{2}$ Grupo de Investigación y Conservación de Killis (GICK). Calle 1222324 , \\ Berisso, Buenos Aires, República Argentina. ${ }^{3}$ Unidad Ejecutora Lillo (UEL)-CONICET-Fundación Miguel Lillo, \\ Miguel Lillo 251, San Miguel de Tucumán, CEP 4000, Tucumán, Argentina. \\ *Corresponding author: felipealonso@gmail.com
}

\begin{abstract}
New records of Corydoras micracanthus from the Bermejo River basin are presented. We confirm the presence of this species in the province of Jujuy, based on deposited material. In addition, its type locality in Lesser, Salta is confirmed, after new data obtained from bibliography regarding the collecting localities of Alfredo Borelli, collector of the type specimens. Additional comments on the behavior, ecology, and conservation status of this species are given.
\end{abstract}

Key words: Biogeography, upper Bermejo River basin, Yungas, endemisms.

Resumen: Distribución geográfica de Corydoras micracanthus Regan 1912 (Siluriformes: Callichthyidae), con comentarios sobre su comportamiento y localidad tipo. Nuevos registros de Corydoras micracanthus en la cuenca del río Bermejo son presentados. Se confirma la presencia de esta especie en la provincia de Jujuy en base a material depositado. Asimismo, confirmamos su localidad tipo en Lesser, Salta, luego de obtener nuevos datos de la bibliografía sobre las localidades de colecta de Alfredo Borelli, colector de los ejemplares tipos. Se proveen comentarios adicionales sobre la ecología y el estado de conservación de esta especie.

Palabras clave: Biogeografía, cuenca alta del Río Bermejo, Yungas, endemismos.

\section{INTRODUCTION}

Corydoras Lacépède, 1803 belongs to the Callichthyidae, in the order Siluriformes. The genus comprises more than 170 valid species widely distributed in the Neotropics (Eschmeyer, 2015).

Corydoras micracanthus was described more than 100 year ago by Regan in a revision of the specimens of the genus Corydoras present in the British Museum of Natural History (BMNH), today called Natural History Museum (Regan, 1912). The description was based on eight specimens collected by Alfredo Borelli, designed as "types" and referred to by Regan as coming from "Salta, Argentina" and 2 additional specimens corresponding to non type material collected by Hermann Joseph Steinbach Kemmerich from the same locality. No precision on the type locality of this species was presented in that work. Later, Ringuelet et al. (1967) cited Corydoras micracanthus for Salta and Jujuy, but unfortunately no vouchers specimens were reported to confirm that identification. Calviño \& Alonso (2009) redescribed this species after examining Corydoras specimens from different basins in Salta and restricted the known distribution to the Mojotoro basin, a tributary of the San Francisco River, which is also a tributary of the Bermejo River.

Additional records from the Bermejo River basin are presented herein and the presence of this species in the province of Jujuy is confirmed, based on voucher specimens deposited at ichthyological collections after an extensive sampling in the area. Also, precision on the type locality is provided based on new data available after revi- 


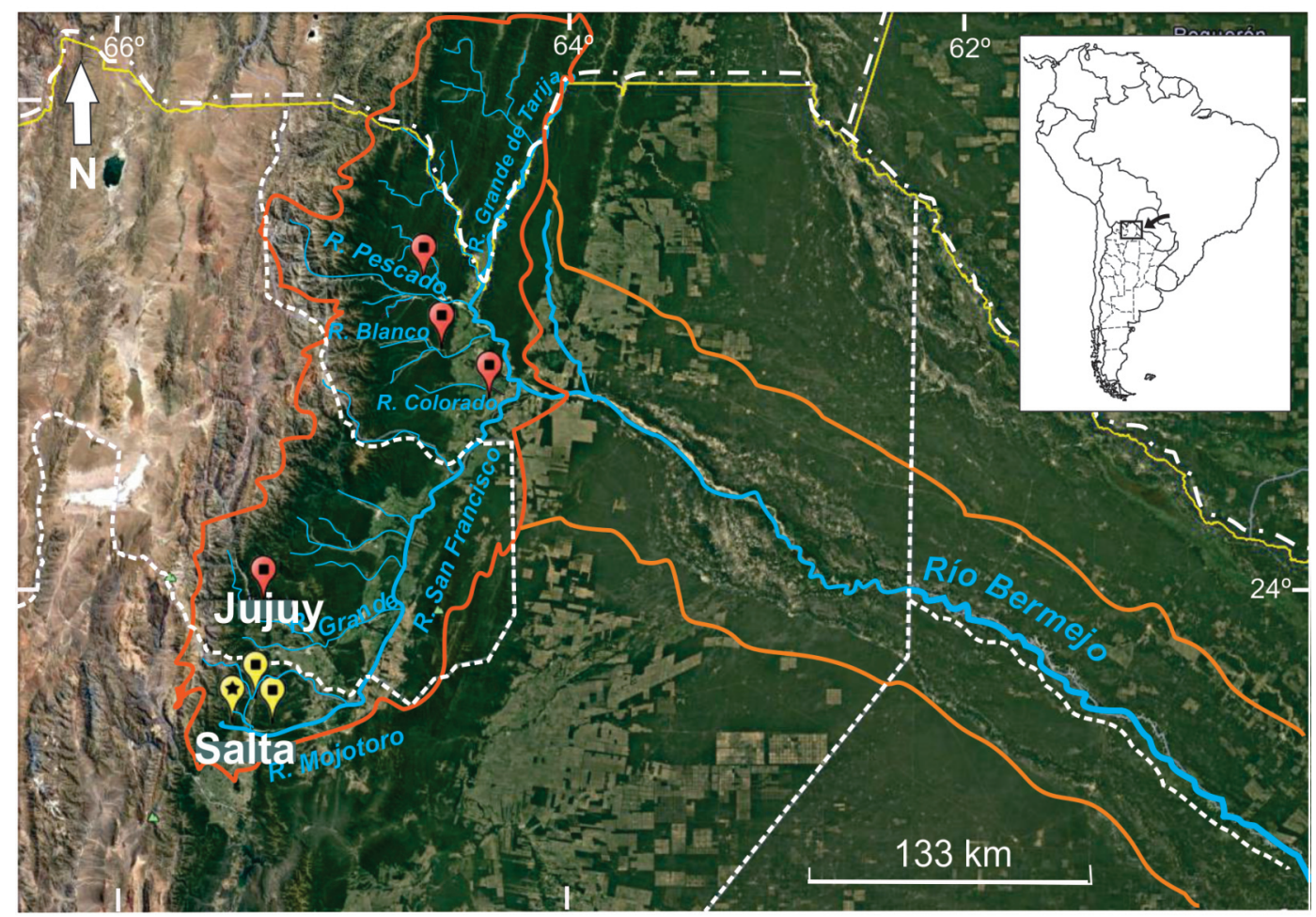

Fig. 1. Geographical distribution of Corydoras micracanthus Regan. Yellow symbol with the star represent its type locality; yellow symbols with the square represent know records based on deposited specimens; red symbols with square symbols represents new records reported herein.

sion of the literature. Further comments on the ecology, behavior and conservation status of this species are provided.

\section{MATERIALS AND METHODS}

We examined all the available material of Corydoras from Salta housed at ichthyological collections from IBIGEO (Salta), Fundación Miguel Lillo (FML) and Museo Argentino de Ciencias Naturales (MACN) and Museo de Ciencias Naturales de Salta, Argentina (MCNI). Also, an extensive sampling was performed by the authors in the last decade in northwestern Argentina. Identification was performed following Calviño \& Alonso (2009).

The behavior was observed ad libitum in situ, after 5 minutes of standing still in the side of the stream at the localities of Lesser and Pintascayo. Additionally, video was recorded with a Panasonic FZ200 and underwater videos were taken with a GoPro Hero3 Black Edition camera. Some specimens were also kept in aquarium for additional observations. A total of 28 hours of direct observation plus 4 hours of video records were done and a qualitative analysis of general behavior and habitat use was followed.

Examined material. Argentina: Salta province: BMNH 1897.1.27.9-14, paralectotype, MACN 9234, (topotypes), 13, Lesser river, La Caldera Department, (S $24^{\circ} 40^{\prime} 39^{\prime \prime}-\mathrm{W} 65^{\circ} 28^{\prime} 33^{\prime}$; altitude: 1463 m.a.s.l.); MACN 9235, 9, same locality as MACN 9234, MACN 9236, 25, Gallinato creek, La Caldera Department, (S $24^{\circ} 40^{\prime} 59^{\prime \prime}$ - W $65^{\circ}$ 17' 32"; altitude 1159 m.a.s.l.); MCNI 498, 5, La Caldera river, La Caldera Department. CIFML 3350, 1, El Oculto crek, Orán Department (23 6'57.49"S, 64³0'0.78”'W); CI-FML 3399, 2, Colorado river, Orán Department (2319'26.34"S, $64^{\circ} 16^{\prime} 57.51^{\prime \prime}$ ); CI-FML 7011, 5, creek on the road from Isla de Cañas to Pintascayo lagoon, Orán Department (2249'52.55'S, 64³4'55.26”'W); CIFML 7014, exit of Campo Alegre dike, La Caldera Department, (243' $\left.35.72^{\prime \prime} \mathrm{S}, 65^{\circ} 22^{\prime} 0.63^{\prime \prime} \mathrm{W}\right)$; CIFML 7280, 25, creek affluent to Itaú river, near Acambuco, (22 ${ }^{\circ}$ '32.05”'S, 6355'42.10”W); Jujuy province: CI-FML 7278, 25, Grande river, at San Salvador the Jujuy city, Doctor Manuel Belgrano, department (2410'36.53”S, 65¹9'22.00”W). 


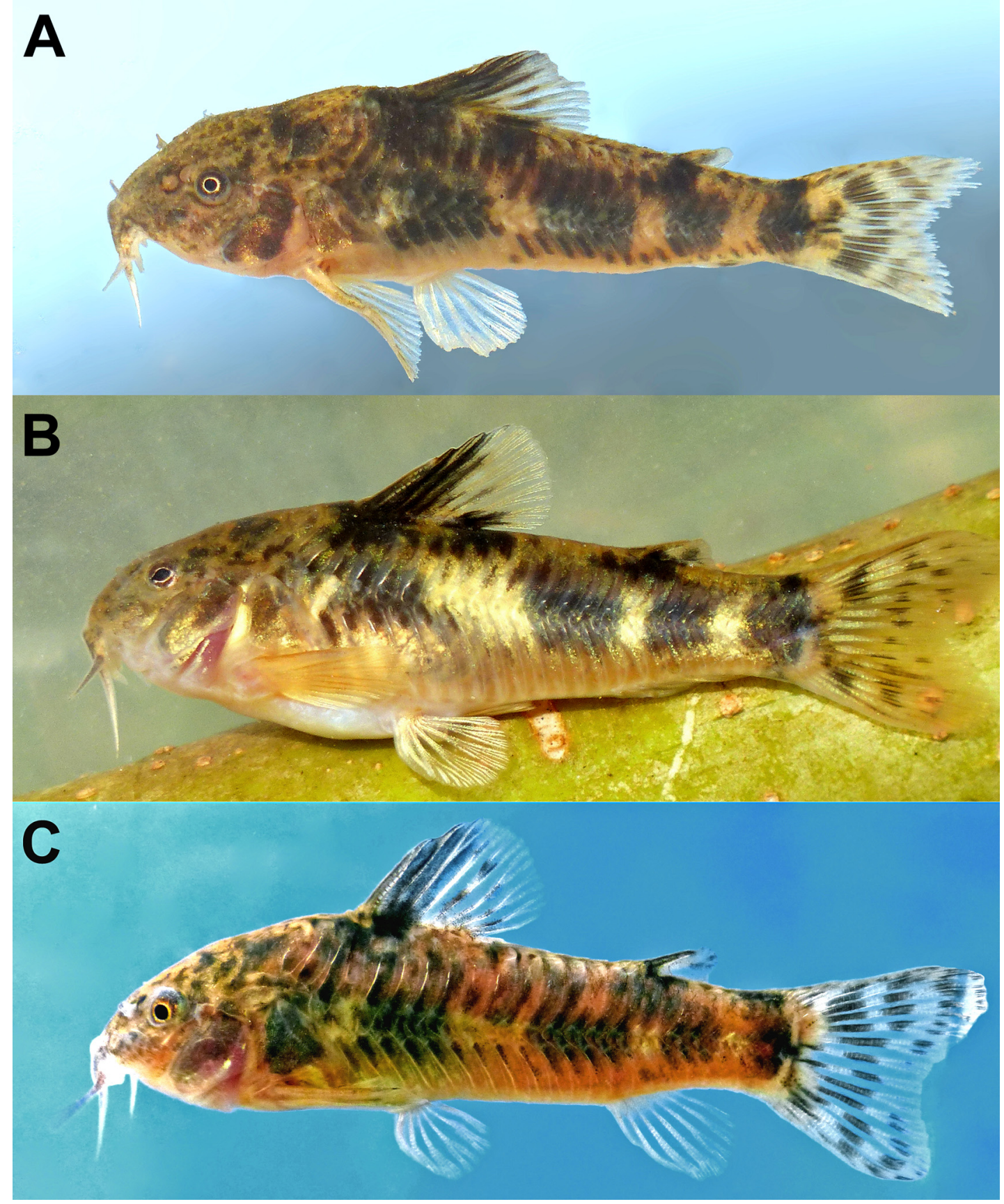

Fig. 2. Live specimens of Corydoras micracanthus Regan in left lateral view. A) From Lesser, type locality of

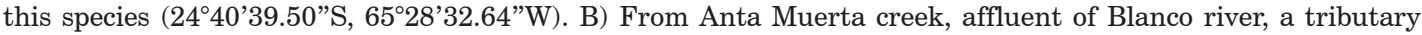

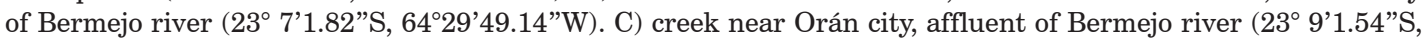
$\left.64^{\circ} 13^{\prime} 49.76^{\prime \prime W}\right)$. Differences in color intensity among these pictures are mainly due to lighting conditions, where figure 2.B was taken under direct sunlight just after collection.

\section{Identification}

Corydoras micracanthus is distinguished from all other species of the genus by the fol- lowing combination of features: 24-26 dorsolateral body plates; $21-22$ ventrolateral body plates; small eyes (9.6-16.5\% of HL); body moderately 


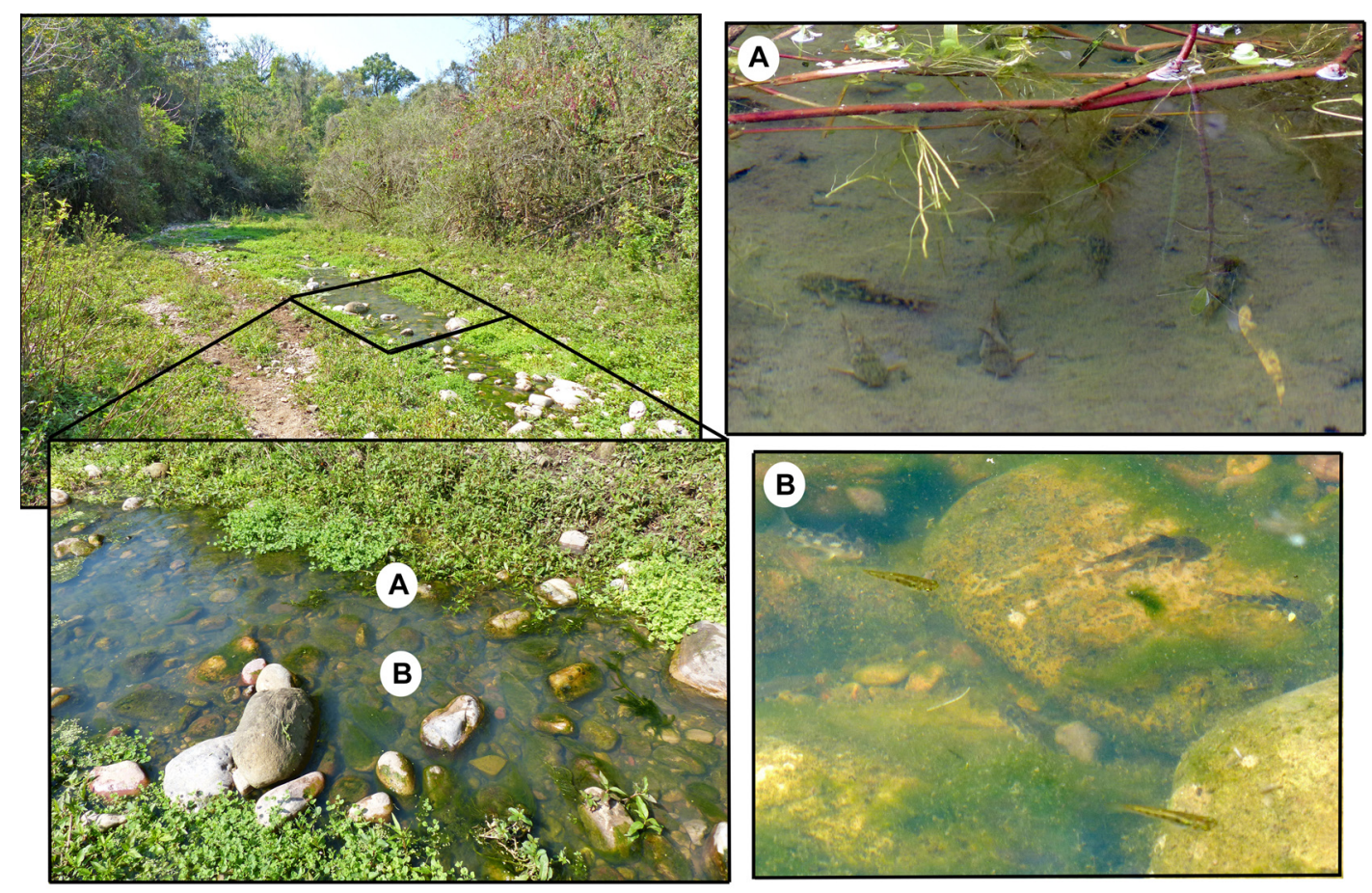

Fig. 3. Creek near Isla de Cañas, tributary of Pescado River where Corydoras micracanthus Regan was particularly abundant together with Jenynsia alternimaculata (Fowler). Inset showing a portion of this environment which had abundant marginal vegetation, slow water flow and clear waters. In sector (B), in open spaced most C. micracanthus specimens are observed actively feeding on the substrate, and some resting in creviced between rocks. In the margins, under aquatic vegetation (A) groups of $C$. micracanthus specimens are observed resting in aggregated patterns.

elongate (body depth 28.1-30.0\% SL); posterior expansion of the parietosupraoccipital process not contacting the predorsal plate; trunk with 4-6 large dark blotches subsquare at junction of body plates; caudal fin slightly emarginated, with joined dark blotches forming 2 or 3 vertical irregular stripe pattern (Calviño \& Alonso, 2009).

\section{RESULTS}

The geographical distribution of this species is here restricted to the upper Bermejo River basin in the Yungas province (sensu Morrone, 2014). Additional records presented show that this species is widely distributed in this area (Fig. 1). The confirmation of this species in Jujuy province based on collection material is provided.

Lesser River was proposed as the most likely type locality by Calviño \& Alonso (2009) as it was assumed that Borelli probably visited Salta city and Lesser was the closest locality to that city where this species is found. Here we found new evidence on the type locality of this species.
Fitfteen years before the description of C. micracanthus by Regan (1912), Boulenger (1897) published a study on the fish specimens collected by Alfredo Borelli during his trip to Argentina and Bolivia. Based on that work we discovered that he collected in two localities in Salta: Lesser and Tala. The last locality (Tala) is near the border with Tucumán and belongs to the Juramento/ Salado River basin were this species is not present. The other locality, Lesser, is in the Bermejo river basin and indeed is the locality proposed in the redescription by Calviño \& Alonso (2009) where $C$. micracanthus is widely distributed, and for this reason it is considered as the most probably type locality for this species. Furthermore, in Boulenger's work there is a list of the specimens collected by Borelli in each locality and the only locality where a member of the Callichthyidae is cited is indeed in Lesser as "Callichthys paleatus Jen". It is noteworthy that C. micracanthus had not been described by then yet, so it is extremely likely that those specimens were misidentified by Boulenger as Corydoras paleatus, another species from La Plata basin. Therefore, it is almost 
certain that the specimens examined by Regan in his description came from that locality, confirming that the type locality of this species is indeed Lesser, in Salta province, Argentina.

Live specimens from different localities can be observed in Fig. 2.

This species is abundant in environments with relatively shallow transparent water, with low current velocity and abundant marginal vegetation as watercress and Ludwigia sp. (Fig. 3). These environments are generally shared with Jenynsia alternimaculata, being these two species dominant in these habitats. Additionally, Heptapterus mustelinus and Trichomycterus spp. are found in these environments. In deeper water bodies $C$. micracanthus can share its habitat with Oligosarcus bolivianus (Fowler, 1940), Astyanax endy Mirande et al., 2006, Asyanax chico Casciotta \& Almirón, 2004 and other species from the area, but it seems to be much less abundant in those conditions.

Individuals of $C$. micracanthus were observed in open spaces (space in the centre of the creek without vegetation) feeding over the surface of the stones, generally in groups of 3-8 specimens. When not feeding, individuals generally are in the marginal vegetation or sometimes in crevices between stones (Fig. 3).

\section{DISCUSSION}

The distribution of $C$. micracanthus seems to be restricted to the upper Bermejo river basin in the Yungas region (sensu Morrone, 2014). This species is widely distributed in this area and is very probably present in Bolivia too. The known distribution of this species is herein extended $210 \mathrm{~km}$. This species was recorded in a range of heights of $330-1450 \mathrm{~m}$ asl in relatively slow current shallow streams with clear waters and abundant vegetation, where it is generally abundant.

We also confirm the type locality of this species based on additional data from literature, which is very important for future comparisons of this species with other taxonomical entities.

The particular conditions described above in the Yungas region where this species is found are dramatically different from those of the Chacoan region where the Bermejo River drains downstream. There, the river changes to a muddy bottom and permanently turbid waters, with scarce aquatic vegetation. This change is probably a barrier for this species as for many other species exclusively found in the area (e.g. Casciotta
\& Almirón, 2004; Mirande et al., 2004a, 2004b, 2006, 2011; Rodríguez and Miquelarena, 2005; Miquelarena and Menni, 2005, Terán et al., 2016) reinforcing the hypothesis that the upper Bermejo River is an area of high endemisms and priority for conservation. In this sense, however, this species does not seem to present any serious immediate concerns on its conservation as it is widely distributed. Nevertheless, special attention should be paid to the conservation of these environments by local administrations. We have observed a common practice in the last years by the local government of canalizing and digging river courses in the areas to prevent floodings. This increases water velocity and eliminates aquatic vegetation making these environments unsuitable for the life of this species.

\section{REFERENCES}

Boulenger, G. A. 1897. Viaggio del Dott. Alfredo Borelli nel Chaco boliviano e nella Repubblica Argentina. Boll. Mus. Zool. Anat. Comp., Univ. Torino 12, 1-4.

Calviño, P. A., \& Alonso, F. 2009. Two new species of the genus Corydoras (Ostariophysi: Siluriformes: Callichthyidae) from northwestern Argentina, and redescription of C. micracanthus Regan, 1912. Revista del Museo Argentino de Ciencias Naturales 11(2), 199-214.

Casciotta, J. R., \& Almirón, A. E. (2004). Astyanax chico sp. n., a new species from the río San Francisco basin, northwest of Argentina (Teleostei: Characiformes: Characidae). Zoologische Abhandlungen-Staatliches Museum fur Tierkunde in Dresden, 54, 11.

Eschmeyer, W. N. (Ed.). 2015. Catalog of fishes: genera, species, references. San Francisco, AC, California Academy of Sciences. 3v., ill. Available from http://researcharchive.calacademy.org/research/ Ichthyology/catalog/fishcatmain.asp . (08 Nov 2017).

Miquelarena, A.M., \& R.C. Menni. 2005. Astyanax tumbayaensis, a new species from northwestern Argentina highlands (Characiformes: Characidae) with a key to the Argentinean species of the genus and comments on their distribution. Revue suisse de Zoologie 112(3): 661-676.

Mirande, J.M., G. Aguilera, \& M.M. Azpelicueta. 2004a. A new species of Astyanax (Characiformes, Characidae) from the upper río Bermejo basin, Salta, Argentina. Revue suisse de Zoologie 111(1): 213-224.

Mirande, J.M., G. Aguilera, \& M.M. Azpelicueta. 2004b. A new genus and species of small characid (Ostariophysi, Characidae) from the upper río Bermejo basin, northwestern Argentina. Revue suisse de Zoologie 111(4): 715-728.

Mirande, J.M., G. Aguilera, \& M.M. Azpelicueta. 2006. Astyanax endy (Characiformes: Characidae), a new 
fish species from the upper Río Bermejo basin, northwestern Argentina. Zootaxa 1286: 57-68.

Mirande, J.M., G. Aguilera, \& M.M. Azpelicueta. 2011. A threatened new species of Oligosarcus and its phylogenetic relationships, with comments of Astyanacinus (Teleostei: Characidae). Zootaxa 2994: 1-20.

Morrone, J.J. 2014. Biogeographical regionalisation of the Neotropical region. Zootaxa 3782(1): 1-110.

Regan, C. T. 1912. XXIV.-A revision of the SouthAmerican Siluroid fishes of the genus Corydoras, with a list of the specimens in the British Museum (Natural History). Journal of Natural History 10(56), 209-220.
Ringuelet, R.A., R.H. Arámburu \& A. Alonso de Arámburu. 1967. Los peces argentines de agua dulce. Comisión de investigación científica. Provincia de Buenos Aires. La Plata. 602 p.

Rodríguez, M.S. \& M.A. Miquelarena. 2005. Una nueva especie de Loricaria (Siluriformes: Loricariidae) para la cuenca del río San Francisco, Jujuy, Argentina. Anales de la Academia Nacional de Ciencias Exactas, Físicas y Naturales 55: 139-149.

Terán, G. E., Jarduli, L. R., Alonso, F., Mirande, J. M., \& Shibatta, O. A. 2016. Microglanis nigrolineatus, a new species from northwestern Argentina (Ostariophysi: Pseudopimelodidae). Ichthyological Exploration of Freshwaters 27(3), 193-202.

Doi: 10.22179/REVMACN.20.564

Recibido: 17-XI-2017

Aceptado: 31-V-2018 